DOI: https://doi.org/10.47405/mjssh.v6i9.1019

\begin{tabular}{|c|c|}
\hline 4 & Malaysian Journal of Social Sciences and Humanities (MJSSH) \\
\hline $\begin{array}{l}\text { Malaysian Juoural of } \\
\text { Social ccciecces and }\end{array}$ & Volume 6, Issue 9, September 2021 \\
\hline (MJ-sSH) & e-ISSN : 2504-8562 \\
\hline & $\begin{array}{l}\text { Journal home page: } \\
\text { www.msocialsciences.com }\end{array}$ \\
\hline
\end{tabular}

\title{
Issues and Challenges in 21st-century Learning of Special Education (Hearing Impaired) in Islamic Education
}

\author{
Norlela Ali ${ }^{1}$, Tengku Sarina Aini Tengku Kasimm ${ }^{1}$, Nor Raudah Siren ${ }^{1}$ \\ ${ }^{1}$ Academy of Islamic Studies, University of Malaya (UM) \\ Correspondence: Tengku Sarina Aini Tengku Kasim (tgsarina@um.edu.my)
}

\begin{abstract}
This study was conducted to identify the challenges of Islamic education teachers in the implementation of the 21st-century learning for the teaching and learning of Islamic education special education hearing impaired. This study is a library review that uses a variety of key reference sources such as books, journals, seminar presentations, conference papers, and various sources from the internet such as websites, as well as official portals that contain information related to the study. All reference sources are analyzed to obtain the facts and detailed information on the topics discussed. The results of the discussion show that there are several challenges identified in implementing learning and facilitation based on the 21st-century learning for Islamic education for hearing-impaired students. Among them are aspects of teacher professionalism, communication skills of teachers and students, application of high-level thinking skills, and teaching facilities. To face the challenges in implementing the 21st-century learning, teachers are advised to constantly improve their knowledge and skills in various fields, especially in the field of Islamic education and special education, in addition to mastering pedagogical skills and educational technology. High commitment from teachers and strong support from the administrators is very necessary in realizing the 21 st-century learning, further able to boost the excellence of special education students with hearing-impaired in fulfilling the aspirations of national education.
\end{abstract}

Keywords: 21 st-century learning, teaching and learning, Islamic education, special education, hearing impaired

\section{Introduction}

In the effort towards making Malaysia a developed country, the field of education has become one of the main platforms to realize that aspiration. Various efforts have been made by the Ministry of Education to strengthen the education system in Malaysia. The Ministry of Education Malaysia (MOE) is responsible for implementing various policies so that Malaysians can compete with developed countries around the world.

To realize this desire, the transformation of education must take place in line with the currents of modernization of the world, especially in the field of education, through the process of teaching and facilitation of teaching and learning. The application of the 21st-century learning is one of the national efforts as contained in the Malaysian Education Development Plan (PPPM) 2013-2025 (Ministry of Education Malaysia, 2013). 
To ensure that all students benefit from the educational transformation outlined in PPPM 2013-2025, the important thing that needs to be emphasized is providing the best educational services that can be enjoyed by all students regardless of differences and background. Therefore, education appropriate to the needs and abilities of children in various journeys of life should be provided to enable all students to have equal educational opportunities.

This includes providing educational facilities to students with disabilities or students with special needs (MBK). The implication is that all of them get the same educational benefits as mainstream students and share the same curriculum system, but are adapted according to their level of ability and functionality. The 21st-century learning-based teaching and learning are also implemented in special education classes to enable MBK to follow the quality of teaching and learning process so that they can possess and master the skills needed in the 21st-century. MBK is expected to be able to compete globally in the 21 st-century in various aspects, in accordance with their abilities and capabilities.

\section{Islamic Education for Special Education (Hearing Impaired)}

Special education programs have been created in line with the PPPM 2006-2025 which is every Malaysian child is entitled to equal educational opportunities so that they can achieve their potential (Ministry of Education Malaysia, 2013). It is also in line with the Person with Disabilities Act 2008 (Act 685) section 28, which is to ensure that the disabled are not left behind in education (Act 685, 2008). Special education programs aimed to provide knowledge and skills through flexible teaching and learning process to meet the needs of individuals with various levels of ability towards the meaningful life (Curriculum Development Division, 2018).

Responding to the challenges in the PPPM 2006-2025 (3rd shift), which is to produce people who appreciate values by strengthening Islamic education and moral education, Islamic education has been made a compulsory subject in the special education curriculum, according to the provisions in Education Act 1996 (Malaysian Law, 2012). The Islamic education curriculum for special education aims to produce people who are knowledgeable, faithful and pious and virtuous by making the alQuran and Sunnah as a guide in daily life to become a successful servant of Allah SWT in this world and the hereafter in accordance with the level of student functionality (Curriculum Development Division, 2018).

The Islamic education curriculum for hearing-impaired students at the primary school level is using the Primary School Standard Curriculum (Hearing Impairment), while hearing-impaired students in secondary schools use the Secondary School Standard Curriculum (KSSM) which is formulated to suit the ability of special education students.

The curriculum for pupil with special educational needs (PSEN) has slightly differences in terms of content standards, learning standards and performance standards. KSSM for special education is easier and simpler compared to KSSM for mainstream. The formulation of this special curriculum makes it easier for teachers to implement the Islamic education curriculum for hearing-impaired students as the curriculum formulated is simpler, relevant and appropriate for the student level. The table below shows an example of the differences between KSSM for special education and KSSM for mainstream in Islamic education (form 1).

For hearing-impaired students in primary schools, Islamic education lessons are divided into AlQuran, akidah, ibadah, sirah, adab and jawi (Curriculum Development Division, 2014). While Islamic education at the secondary school level is divided into the field of al-Quran, the field of hadith, the field of faith in the field of worship, the field of sirah and the field of morality (Official Portal of Curriculum Development Division, 2015). 
Table 1: The differences between KSSM for special education and KSSM for mainstream in Islamic education (form 1).

\begin{tabular}{|c|c|c|}
\hline & KSSM (Mainstream) & KSSM (Special Education) \\
\hline CONTENT & 3.1 Islam is a religion of nature & 5.1 Recognize the pillars of Islam \\
\hline STANDARDS & 3.2 Aqidah Islam & 5.2 Explain the meaning of $D u a$ \\
\hline & 3.3 Believing in Allah & Kalimah Syahadah \\
\hline (Aqidah) & $\begin{array}{l}\text { 3.4 The Name of Allah (al- } \\
\text { Khaliq and al-Musawwir) }\end{array}$ & $\begin{array}{l}5.3 \text { Explain the obligation of } \\
\text { obligatory prayers }\end{array}$ \\
\hline $\begin{array}{l}\text { LEARNING } \\
\text { STANDARDS }\end{array}$ & $\begin{array}{l}\text { 1.1.1. Read verses one to five of } \\
\text { Surah Al-Baqarah correctly and } \\
\text { with tajweed }\end{array}$ & $\begin{array}{l}\text { 1.1.1. Read verses one to two of } \\
\text { Surah Al-Baqarah } \\
\text { 1.1.2. Read verse three of Surah Al- }\end{array}$ \\
\hline (Al-Quran) & $\begin{array}{l}\text { 1.1.2. State the main content of } \\
\text { the verse } \\
\text { 1.1.3. Memorize verses one to } \\
\text { five of Surah Al-Baqarah } \\
\text { correctly and with tajweed } \\
\text { 1.1.4. Practicing verses one to } \\
\text { five of Surah Al-Baqarah in } \\
\text { prayer and memorize in a } \\
\text { civilized and istiqomah }\end{array}$ & $\begin{array}{l}\text { Baqarah } \\
\text { 1.1.3. Read verse four of Surah Al- } \\
\text { Baqarah } \\
\text { 1.1.4. Read verse five of Surah Al- } \\
\text { Baqarah } \\
\text { 1.1.5. Read verses one to five of } \\
\text { Surah Al-Baqarah } \\
\text { 1.1.6. Apply the long and short signs } \\
\text { of verses one and five of Surah Al- } \\
\text { Baqarah }\end{array}$ \\
\hline PERFORMANCE & Level 1 & $\underline{\text { Level } 1}$ \\
\hline $\begin{array}{l}\text { STANDARDS } \\
\text { (Akhlak - Manners Of } \\
\text { Seeking Knowledge) }\end{array}$ & $\begin{array}{l}\text { State the obligation to seek } \\
\text { knowledge with propositions, } \\
\text { manners of seeking knowledge, } \\
\text { the importance of being civilized } \\
\text { when seeking knowledge, the } \\
\text { consequences of not being } \\
\text { civilized when seeking } \\
\text { knowledge, and the advantages of } \\
\text { people who are knowledgeable } \\
\text { and seek knowledge. }\end{array}$ & $\begin{array}{l}\text { States in general the manners in } \\
\text { seeking knowledge }\end{array}$ \\
\hline
\end{tabular}

Source: DSKP Pendidikan Islam Tingkatan 1 (2015) and DSKP Pendidikan Islam Pendidikan Khas Tingkatan 1 (2015)

The 21st-century skills and high-level thinking skills are among the important elements contained in the special education curriculum and assessment (DSKP) standard documents to be applied in teaching and learning according to content standards, learning standards and performance standards to measure students' level of mastery or skills (Ministry of Education Malaysia, 2018). The application of the 21st-century learning skills is implemented in teaching and learning activities to enable hearingimpaired students to acquire the same 21st-century learning skills as their peers in the mainstream and so that they are able to compete globally according to their level and ability.

\section{The 21st-Century Education in Education System}

21st-century skills have become a phenomenon that serves as a benchmark leading to the progress and modernity of a country. The Ministry of Education Malaysia has launched a pilot 21st-century learning initiative in 2014 and expanded its implementation nationwide starting in 2015. 
The 21st-century skills are generally understood to encompass a wide range of competencies, including critical thinking, problem solving skill, creativity, meta-cognitive, communication, digital and technological literacy, civic responsibility, and global awareness (Sharon Kim et.al, 2019). The 21 st-century learning in the education system involves the development of human capital that is competitive globally, has creative and critical thinking skills, and is able to solve various problems (McCrae, 2011).

The 21st-century learning is student-centered learning based on communication, collaborative, critical thinking, and creativity as well as the application of good values and ethics (Ministry of Education Malaysia, 2013). Every student needs to master the 21 st-century skill elements such as creativity and innovation, critical thinking and problem solving, communication and collaborative, information literacy skills, information technology literacy and communication technology (Mashira et al., 2019). All of these elements need to be applied by teachers to students during the teaching and learning process.

The application of $21^{\text {st }}$ learning century leads students to learn in a conducive learning environment, and will feel engaged and educated with learning experiences in school. Upon graduation, students will have world-class knowledge and skills, high moral values, and be able to compete with peers from other countries (Ministry of Education Malaysia, 2013). The application of 21st-century learning skills helps students face competition both in terms of education and in future careers (Mashira et al., 2019).

In conclusion, the main goal of 21 st-century learning is to encourage lifelong learning to produce a knowledgeable generation who has various skills to ensure the continuity of life in an increasingly challenging global age. The 21st-century learning emphasizes the student-centered learning and higher order thinking skills implemented in the teaching and learning process through the preparation of a systematic teaching plan, followed by the implementation of active teaching and learning that implements the 21st-century learning activities.

\section{The Challenges of the 21st-Century Learning in Islamic Education for Hearing- Impaired Students}

In order to achieve the goal of making the 21 st-century learning as a platform in teaching and learning, all teachers should be ready and ensure that all students can learn and master learning through the 21st-century learning activities according to the level and ability of students. Quality teachers who are ready to face challenges are the backbone of the Ministry of Education to realize the transformation of the country's education as intended through the Malaysian Education Development Plan 2013-2025. (Bulletin, 2015).

Thus, teachers should act as planners, controllers, mentors, motivators and assessors while students act as active learners. The change will occur when teachers implement 21st-century learning, as stated in the second wave of Malaysia Education Quality Standard (SKPMg2). Teachers are facilitators that enable students to explore learning independently by implementing activities in the form of problem solving skills and higher order thinking skills collaboratively and cooperatively (Ministry of Education Malaysia, 2019b). The role of teachers is important to ensure the teaching and learning process is implemented effectively and student achieves the standards set in the learning objectives.

The reality is, teachers often face various challenges in implementing the 21 st-century learning. The challenges emerge from various aspects, both in terms of teachers, students, teaching resources, learning facilities, administration and so on. For Islamic education subjects, Islamic education teachers, especially those who teach in hearing-impaired classes, also do not miss the various challenges of implementing the 21st-century learning in teaching and learning such as teacher professionalism aspects, communication skills of teachers and students, application of high-level thinking skills, and teaching facilities. 
As the individual who responsible for mobilizing the teaching and learning process in the classroom, aspects of teacher professionalism are important things that need to be addressed. This is in line with what is outlined in SKPMg2 that teachers play the role of planners, controllers, mentors, motivators and evaluators (Ministry of Education Malaysia, 2019b). Therefore, competent teachers are needed in implementing teaching and learning to ensure that its implementation applies smoothly, effectively and meets learning objectives.

The important thing that Islamic education teachers needs to have is the extensive knowledge (Kamarul, 2010) master the subjects taught as contained in the teaching curriculum (Syed Mahadzir, 2005), as well as master the curriculum, pedagogy and teaching techniques (Norfishah, 2016). In this case, it is clear that Islamic education teachers must be skilled and master in knowledge of Islamic religious education and have teaching skills, in accordance with its role as a teacher of Islamic education.

However, for Islamic education teachers who teach hearing-impaired classes, the aspect of professionalism is one of the challenges they face, because there are among Islamic education teachers who teach Islamic education in special education integration program who are not among the Islamic Education option teachers themselves, and there are among Islamic education teachers who teaching in hearing-impaired class are among the special education option teachers of learning disabilities (Nik Hassan Seman, et.al, 2016). This means that there are Islamic education teachers assigned to teach in hearing-impaired classes, but are not according to their options and expertise. This definitely poses a problem because each field of knowledge is different from each other in terms of content and teaching methodology (Ab Halim et al., 2012), pedagogy and practices.

To communicate with hearing-impaired students, teachers need to master few skills such as sign language, interpersonal skills and intrapersonal skills (Nurzuliana, 2018). These skills are needed to facilitate the process of delivery to teach and facilitate students' understanding of the topics taught. To teach abstract concepts in Islamic education to hearing-impaired students is not an easy task because they have problems in understanding abstract matters and terms in Islamic education, especially those involving matters of faith and akidah (Mohd Huzairi, 2017). Without proper pedagogical, communication and psychological skills in understanding the learning culture of hearing-impaired students, Islamic education teachers will face various difficulties, especially in planning and implementing the 21 st-century learning activities in teaching and learning. A study by Mohd Rizal and Muallimah (2010) found that teachers who do not have a professional qualification in the field of special education are found to be difficult to deliver teaching and learning, as they need additional training and workshops to develop their teaching skills.

However, this challenge can be overcome if teachers strive to ensure that they have the knowledge, skills and expertise in the field taught and always improve their professionalism by attending training or related courses so that teaching and learning can be carried out well and the 21 st-century learning activities can be implemented effectively.

Aspects of communication also need to be given attention in implementing the 21 st-century learning. Communication is an important element in teaching and learning because it is a medium of interaction between teachers and students and students with fellow students in the teaching and learning process. Effective communication enables teachers to deliver lessons and students to understand learning well and effectively. Communication skills are one of the elements of the 21 st-century learning that needs to be applied by teachers to ensure that students are able to master it.

For hearing-impaired students, their main challenge is in the aspect of communication. Deafness and disability in the auditory senses, causing the oral communication of students with hearing impairment is also affected. Hearing-impaired students have speech problems that cause them not to be able to read learning materials (Mohd Huzairi et al., 2012). They are also usually found to be difficult to initiate pronunciation and even no sound is produced (Mustafa Che et al., 2015). Their speech is also limited, besides having difficulty in answering comprehension, reading, and writing questions 
(Kodiango \& Syomwene, 2016). Lacking of language and speech aspects lead students with hearingimpaired more comfortable using sign language as their communication tool.

Standard sign language helps to improve the quality of communication between teachers and students and, ultimately improve the quality of education and future life of deaf and hard-of-hearing students (Kayi et al., 2019). The use of sign language can attract hearing-impaired students to learn and improve their understanding in learning (Syar Meeze \& Norlidah, 2017). So, it is clear that for the teaching and learning process, sign language is the best medium of communication between teachers and students and students with other students. This means that teachers and students need the sign language skills to ensure that they can communicate well.

However, the challenges in teaching and learning raised when there are constraints in communication due to Islamic education teachers who are less proficient in sign language and there are hearingimpaired students themselves who prefer to use gestures when communicating with teachers rather than using sign language (Nik Hassan et al., 2016). Lacking of teachers' skills in using sign language makes it difficult for students to understand what is taught by teachers (Syar Meeze \& Norlidah, 2017) and causes students to be less interested in learning religion (Mohd Huzairi, 2017). In addition, the lack of religious sign words makes it difficult for students with hearing-impaired to master a concept, and also most words related to concepts in Islamic education cannot be explained through the use of sign language (Syar Meeze et al., 2017). This affects communication and interaction among hearingimpaired teachers and students while implementing the teaching and learning process which will eventually cause difficulties in implementing various activities, especially 21 st-century learning activities that involve many communication skills.

In addition, one of the issues emphasized in 21st-century learning is to apply higher order thinking skills to students. Today, every student needs to master various cognitive skills including reasoning and critical thinking, creative and innovative. However, this field is given less attention, causing students to be less able to apply knowledge and think critically outside the academic context (Ministry of Education Malaysia, 2013).

To implement higher order thinking skills in teaching and learning Islamic education among hearingimpaired students is not an easy task because students with hearing-impaired are found to be weak in academics (Mohd Huzairi, 2017). There are studies showing that they are less interested in the subject of Islamic education and most of them do not have a strong Islamic foundation in Islamic education (Mohd Huzairi et al., 2012). Students' motivation is also low because they feel they are unable to learn, quickly give in and admit about their weaknesses because they do not apply the nature of wanting to try (Mustafa et al., 2015). This factor leads to student learning which causes them to lack of self-confidence, and this prevents them from thinking creatively and critically.

Hearing-impaired students are also found to have difficulty memorizing the verses of the al-Quran because easy to forget and difficult to rearrange the verses of the al-Quran that have been memorized (H. Ahmad et al., 2018; Mohd Huzairi et al., 2012). This makes it difficult for them to apply higher order thinking skills at a higher level. Thus, in order to help students mastering the 21 st-century learning skills, teachers should use appropriate methods and teaching aid materials for hearingimpaired students. The best method for teaching and learning students with hearing-impaired is to use a visual and kinesthetic teaching approach (Hamdi et al., 2012; Luqman et al., 2017). The information technology -assisted learning by combining words and pictures in multimedia materials, helps students learn better than using words alone (Clare, 2004; Mardiyanti et al., 2017). Visual learning can help students in the process of reading, understand abstract learning and can strengthen students 'concepts and understanding (Luqman \& Hidayatulloh, 2017) and improve vocabulary for communication purposes (Lidstorm \& Hemmingsson, 2014).

Research shows that learning visually helps a lot of hearing-impaired people to understand a term or terms that is difficult to understand. (Mardiyanti, Putu \& Haryanthi, 2017). Therefore, teaching aid materials used should also be student-friendly and appropriate to the level of students according to their level and ability. However, teaching aid materials for the use of hearing-impaired students is not 
much on the market (Mohd Rizal \& Muallimah, 2010). Lack of suitable teaching aid materials is one of the factors that affect the teaching and learning process of Islamic education (Ainul \& Manisah, 2015). This should be taken into account by teachers because teaching aid materials is one of the alternatives that can be used and can encourage material-centered learning collaboratively with peers, as found in the 21 st-century learning skills.

\section{Recommendations}

Based on the findings from the studies conducted, it was found that there are various challenges that need to be faced by Islamic education teachers who teach hearing-impaired class in implementing the 21 st-century learning in teaching and learning. To ensure that all these challenges can be encountered well, Islamic education teachers must always be positive and think of the best way to overcome all challenges.

In terms of increasing professionalism, Islamic education teachers needs to have extensive knowledge in various fields, especially areas related to their teaching. Teachers should have knowledge of the content of the subjects taught (expertise in the subject) and it should be constantly updated (Saedah Siraj \& Mohammed Sani, 2012) and improved in line with current needs. Teachers need to practice continuous learning, always updated with the development of education, and be prepared to face various challenges ahead (Subahan \& Syed Ismail, 2017).

The ongoing knowledge related to the latest pedagogy also needs to be mastered by teachers. Teachers need to be proficient in teaching, managing classes using appropriate learning modes, methods and teaching technologies in teaching and learning (Saedah Siraj \& Mohammed Sani, 2012). This is important to enable teachers to have knowledge and understanding of teaching and learning and implement the 21 st-century learning more effectively and systematically as well as further inculcate these skills in students.

Islamic education teachers need to be prepared with knowledge and skills related to educational technology and make multimedia and ICT-assisted teaching one of the 21st-century teaching mediums. In addition to encouraging active and student-centered learning, the use of multimedia in teaching and learning can ensure those hearing-impaired students do not left behind in the currents of educational modernity and respond to the challenges of 21 st-century learning based on information technology and telecommunications skills.

Although ICT is one of the important elements in 21st-century learning, the constraints in providing and using ICT facilities should not be an obstacle or a burden to Islamic education teachers to implement 21st-century learning. Teachers need to be more creative and use whatever teaching methods are effective and appropriate to the level and ability of students by ensuring that the activities implemented are student-centered (Ministry of Education Malaysia, 2019a). Many 21st-century learning activities can be explored by teachers and applied in Islamic education subjects, in accordance with the teaching and learning of hearing-impaired students. These activities can be browsed from websites and blogs run by excellent Islamic education teachers as well as other teachers who always apply the 21st-century learning in their class.

Islamic education teachers should always train students to answer questions in the form of higher order thinking skills, in accordance with student's understanding to train students' creative and critical thinking. Questioning techniques can also be implemented by asking students in an easy-to-understand and creative way so that students are more interested in answering the questions posed by the teacher. Alternatively, teachers can also create activities such as quizzes or competitions for students to ask the most questions by providing rewards to encourage students to ask more questions (Ministry of Education Malaysia, 2019b). Therefore, the constraints in terms of the use of ICT can be overcome by implementing 21 st-century learning activities aimed at student-centered activities, thus encouraging communication between students and improving thinking skills. 
School administrators should always provide encouragement such as moral and financial support to Islamic education teachers to enable them to implement various activities, action research and innovation in teaching and learning (Norakyairee et al., 2019). The involvement of Islamic education teachers in action research and innovation competition is important for the purpose of sharing knowledge and current educational technology that is suitable for the hearing impaired. In addition, participation in action research and innovation can encourage Islamic education teachers to be more creative and innovative in providing more up-to-date teaching aid materials and meeting 21 st-century learning. Special education teachers need to produce more software that helps in teaching and learning because they have better understanding on the abilities and needs of students, as well as ensuring the software built meets the needs of hearing-impaired students (Lajiwin, 2012). Involvement in competitions and sharing of teaching and learning materials allows Islamic education teachers to share the latest information and teaching aid material with fellow teachers from various countries and build a better and more useful communication network.

To balance the problems that exist related to options and professional issues among Islamic education teachers who teach in hearing-impaired classes, educational institutions need to create options for Islamic Education Special Education in teacher training. In reality, at the teachers' training institutions, especially in the Institute of Teacher Education (IPGM), Islamic Education and Special Education options are two different options. If these two options are combined, it is easy for prospective Islamic education teachers to teach special education classes because they have obtained clear information about special education students (Norakyairee et al., 2019). With the combination of the two specialties in an option, it will definitely facilitate the Islamic education teachers that will teach special education classes and improve the teaching quality of the Islamic education teachers involved.

Teacher training institutions can also include special education curriculum specifically related to hearing-impaired as part of the teacher training curriculum to enable prospective teachers to have sufficient knowledge and preparation in dealing with hearing-impaired in the context of special needs schools (Kayi et al., 2019). This is important to ensure that novice teachers have basic knowledge related to special education and are more competent in implementing teaching and learning.

Global competition requires teacher education to support multi-skills learning to enable them to compete in the global market. Ongoing teacher training through in-service courses can be seen as the potential to create adaptive skills in the 21st-century (Voogt, Erstad, Dede, \& Mishra, 2013). Ongoing training in organizations and courses should be prepared and provided to Islamic education teachers as exposure in terms of knowledge, skills and attitudes so that teachers can improve their competencies and job performance.

\section{Conclusion}

There have been various efforts made to realize 21 st-century learning in teaching and learning to ensure the country's education system quality, comparable to developed countries and able to compete globally. At the school level, the same challenges are faced by Islamic education teachers who teach hearing-impaired classes, namely challenges in improving teacher professionalism, communication skills, use of educational technology resources, and the application of higher order thinking skills in teaching and learning. To ensure that 21 st-century learning continues to apply smoothly and effectively, Islamic education teachers must always be prepared and improve the professionalism of teachers in terms of knowledge and skills of teachers. The teaching and learning process carried out must comply with the concept of 21 st-century learning and be implemented according to the ability and level of hearing-impaired students so that students could easily receive lessons, enjoy learning, and can improve student performance optimally. All parties need to work together and redouble their efforts to boost the quality of education in our country to be on par with the quality of education at the international level. 


\section{References}

Ainul Yaqin Abdullah \& Manisah Mohd Ali. (2015). Mastery of Pillars of Prayer Among the HearingImpaired Students. Jurnal Penelitian Dan Pengembangan Pendidikan Luar Biasa, 5(1), 1-6.

Akta 685. (2008). Akta Orang Kurang Upaya 2008. Retrieved from http://rehabmalaysia.org/wpcontent/uploads/2011/12/Akta-Orang-Kurang-Upaya-2008.pdfdivision

Curriculum Development Division. (2014). Dokumen Standard Kurikulum Dan Pentaksiran Pendidikan Islam Pendidikan Khas (Maslaah Pendengaran) Tahun 5. Putrajaya: Kementerian Pendidikan Malaysia.

Curriculum Development Division. (2018). Kurikulum Pendidikan Khas. Retrieved March 11, 2018, from http://bpk.moe.gov.my/index.php/terbitan-bpk/pendidikan-khas

H. Ahmad, N. M. M. Zainuddin, R. Ali, N. Maarop, R. C. M. Yusoff, W. A. W. Hassan, . (2018). Augmented Reality To Memorize Al-Quran For Hearing-impaired Students: A Preliminary Analysis. Journal Of Fundamental and Applied Sciences, (Special Issue), 91-102. https://doi.org/http://dx.doi.org/10.4314/jfas.v10i2s.8

Kamarul Azmi Jasmi. (2010). Guru Cemerlang Pendidikan Islam Sekolah Menengah di Malaysia: Satu Kajian Kes. Tesis Ph.D, Universiti Kebangsaan Malaysia (Tidak diterbitkan)

Kayi Ntinda, S'lungile K.Thawal, Bonginkhosi Tfusi, . (2019). Experiences of Teachers of Deaf and Hard-of-Hearing Students' in a Special Needs School: An Exploratory Study. Journal of Education and Training Studies, 7(7 (July)), 79-89. Retrieved from http://jets.redfame.com

Kodiango, W. O., \& Syomwene, A. (2016). Challenges Faced By The Hearing-impaired Learners In Composition Writing And In Answeringcomprehension Questions During English Language Lessons. European Journal of Eduzation Studies, Volume 2 (Issue 10). 1-13. https://doi.org/DOI: 10.5281/zenodo.166048

Lajiwin@ Jovinia Kudun. (2012). Pengajaran Makna Perkataan Bagi Murid Bermasalah Pendengaran Menggunakan Perisian Pengajaran Dan Pembelajaran Berbantukan Komputer. Jurnal Penyelidikan Kent, 10.

Mashira Yahaya, Rusyati Hanafiah, Nor Sazila Zakaria, Rohana Osman, Khairul Anuar Bahrin, . (2019). Amalan Pembelajaran Abad Ke-21 Dalam Pengajaran Dan Pemudahcaraan (PdPc) Gurguru Sekolah Rendah. Jurnal IPDA, 26, 13-24.

Ministry of Education Malaysia. (2018). Dokumen Standard Kurikulum dan Pentaksiran Pendidikan Islam Pendidikan Khas Tingkatan 4 \& 5. Putrajaya: Kementerian Pendidikan Malaysia.

Ministry of Education Malaysia. (2013). Pelan Pembangunan Pendidikan Malaysia 2013-2025.

Ministry of Education Malaysia. (2019a). Pembelajaran Abad Ke-21 (PAK21). Putrajaya: Kementerian Pendidikan Malaysia. Retrieved from https://www.cikgupress.com/2019/10/pembelajaran-abad-ke-21-pak21.html

Ministry of Education Malaysia. (2019b). SKPMg2. Retrieved April 23, 2019, from http://jpnperak.moe.gov.my/ppdhilirperak/attachments/article/2560/01-Pelaksanaan SKPMg2.pdf

Mohd Huzairi Awang, Hajarul Bahti Zakaria \&, Rahimin Affandi Abd Rahim, . (2012). Pendidikan Islam Golongan Masalah Pendengaran: Tinjauan Awal Isu Dan Cabaran Dari Perspektif Guru. Jurnal Sains Humanika, 58(1), 135-139. https://doi.org/https://doi.org/10.11113/sh.v58n1.213

Mohd Huzairi Awang@Husin. (2017).Penghayatan fardu ain remaja pekak di Malaysia. Jabatan Fiqh dan Usul, Akademi Pengajian Islam, Universiti Malaya.

Mohd Rizal Mohd Said \& MuallimahArshad. (2010). Masalah Guru Pendidikan Khas Program Integrasi Dalam Pengajaran Dan Pembelajaran Kemahiran Hidup Di Sekolah Menengah , Daerah Kota Tinggi, Johor. Unpublished, 1-8. Retrieved from https://www.researchgate.net/publication/279663309_Masalah_Guru_Pendidikan_Khas_Progra m_Integrasi_Dalam_Pengajaran_Dan_Pembelajaran_Kemahiran_Hidup_Di_Sekolah_Menenga h_Daerah_Kota_Tinggi_Johor

Mustafa Che Omar, Nik Hassan Seman, Abdullah Yusoff, \& Abdul Hakim Abdullah, . (2015). Kesukaran Mengajar Dan Belajar Al-Quran Dalam Kalangan Pelajar Pekak : Isu Dan Cabaran Guru Pendidikan Islam. In SQ 2015 eProceedings International Seminar on al-Quran in Contemporary Society 10 - 11 October 2015. Faculty of Islamic Contemporary Studies, UniSZA.

Nik Hassan Seman, Mustafa Che Omar, Abdullah Yusoff, Mohd Yusoff Abdullah. (2016). Analisis 
permasalahan pelajar cacat pendengaran dalam pembelajaran mata pelajaran pendidikan Islam di Malaysia. Jurnal Ilmi, (6), 105-124.

Norakyairee Mohd Raus, Mohd Nur Adzam Rasdi, \&, Nurutthoilah Mohd Nabil, . (2019). Pendidikan Agama Dalam Kalangan OKU: Isu dan Cabaran Semasa. In Seminar Kesedaran Pendidikan KAFA $O K U$ (pp. 1-16). Kuala Lumpur: Jabatan Kemajuan Islam Malaysia.

Norfishah Mat Rabi. (2016). Transformasi Pendidikan Murid Kurang Upaya. Perak: Penerbit Universiti Pendidikan Sultan Idris.

Nurzuliana, S. M. N. \& Z. (2018). Peranan dan cabaran guru-guru pendidikan khas membentuk kemenjadian murid-murid masalah pendengaran dalam abad ke 21. JQSS - Journal of Quran Sunnah Education and Special Needs, 1(June), 1-8.

Portal Rasmi Bahagian Pembangunan Kurikulum, (2015). DSKP Pendidikan Islam Pendidikan Khas Tingkatan 1. Retrieved February 23, 2018, from http://bpk.moe.gov.my/index.php/terbitanbpk/pendidikan-khas/category/146-dskp-tingkatan-1

Portal Rasmi Bahagian Pembangunan Kurikulum, (2015). DSKP Pendidikan Islam Pendidikan Khas Tingkatan 1. Retrieved Mac 3, 2021, from http://bpk.moe.gov.my/index.php/terbitanbpk/kurikulum-sekolah-menengah/category/16-dskp-tingkatan-1

Saedah Siraj \& Mohammed Sani. (2012). Standard Kompetensi Guru Malaysia, 41-44. Retrieved https://www.academia.edu/13727679/Standard_Kompetensi_Guru_Malaysia

Sharon Kim, Mahjabeen Raza, Edward Seidman. (2019). Improving 21st-century teaching skills: The key to effective 21 stcentury learnerstle. Research in Comparative \& International Education, 14(1), 99-117. https://doi.org/https://doi.org/10.1177/1745499919829214

Subahan Mohd. Meerah \& Syed Ismail Syed Mustapa. (2017). Pedagogi Abad Ke-21. Petaling Jaya: Sasbadi Sdn. Bhd.

Syar Meeze Mohd Rashid, Norlidah Alias, \& Zawawi Ismail, . (2017). Isu dan Cabaran Dalam Penggunaan Bahasa, Bahasa Isyarat Malaysia (BIM) untuk Pengajaran Perkara Asas Fardhu Ain (PAFA). J-QSS - Journal of Quran Sunnah Educaion and Special Needs, 1 No 1(June), 1-14.

Syed Mahadzir. (2005). Pendidikan Islam. Seri Kembangan: Penerbit PCT Sdn Bhd.

Tamuri, A. H., Ismail, M. F., \& Jasmi, K. A. (2012). Komponen Asas Untuk Latihan Guru Pendidikan Islam. Global Journal Al Thaqafah, 2(2), 53-63. https://doi.org/10.7187/GJAT232012.02.02

Undang-undang Malaysia. (2012). Akta Pendidikan 1996 (Akta 550). Retrieved from https://www.moe.gov.my/index.php/my/pekeliling/pekelilling-ikhtisas/item/164-aktapendidikan-1996-dan-peraturan-peraturan

Voogt, J., Erstad, O., Dede, C., \& Mishra, P. (2013). Challenges to learning and schooling in the digital networked world of the 21st-century. Journal of Computer Assisted Learning. https://doi.org/10.1111/jcal.12029 